\title{
Hydrogen as a clean and sustainable energy for green future
}

\author{
Samy Yousef \\ Department of Production Engineering, Faculty of Mechanical Engineering and Design, Kaunas University \\ of Technology, LT-51424 Kaunas, Lithuania \\ Department of Materials Science, South Ural State University, Lenin Prospect 76, 454080, Chelyabinsk, \\ Russia \\ E-mail: ahmed.saed@ktu.lt
}

Received 7 April 2021; received in revised form 22 April 2021; accepted 30 April 2021 DOI https://doi.org/10.21595/stge.2021.21985

Check for updates

Copyright (C) 2021 Samy Yousef. This is an open access article distributed under the Creative Commons Attribution License, which permits unrestricted use, distribution, and reproduction in any medium, provided the original work is properly cited.

\begin{abstract}
Hydrogen is the most abundant gas in the universe and is classified by the World Energy Organization as the cleanest fuel in the world compared to other energy products. Therefore, the hope hangs upon it in achieving the zero fuel emissions strategy, which adopted by the largest countries in the world. Also, it is believed that by 2050, hydrogen consumption will represent $24 \%$ of the global energy sector, with investments estimated at 2.5 trillion dollars, compared to only 139 billion dollars at present. There are three types of hydrogen (gray, blue and green) classified based on their production methods and carbon content. Gray hydrogen is usually produced by burning natural gas at high temperatures and once the carbon is removed or captured, the gray hydrogen turns into blue hydrogen. As for green hydrogen with zero emissions, it is produced through the electrolysis of water or by using renewable energy sources such as solar cell, wind energy, etc. to avoid any emissions during the production stages. Despite the efficiency of green hydrogen compared to other types, its price remains a major obstacle in the promotion and marketing, which is estimated at $3.5 \mathrm{Euro} / \mathrm{kg}$, compared to $1.5 \mathrm{Euro} / \mathrm{kg}$ for blue hydrogen. In addition to some other obstacles related to infrastructure and raw materials used in the production stages. Recently, and in order to remove all these obstacles, the leading countries in the energy sector pumped more investments to study all these obstacles and assess the current hydrogen market, which in turn leads to the acceleration of the upscaling of hydrogen production. In this context, this research was developed to study all these current and future challenges. In addition to discussing the traditional and modern methods of its production. Besides taking a look at the projects under implementation in this regard.
\end{abstract}

Keywords: hydrogen, sustainable energy, clean energy, zero fuel emissions, renewable energy.

\section{Introduction}

Since the beginning of creation, energy sources have been one of the main challenges facing every era, from the Stone Age to the post-industrial era. The common challenge between these ages was to find other sources of energy production with a high calorific value until the discovery of fossil fuels in the seventeenth century [1]. However, due to the many constraints related to emissions and sustainability, decision-makers have rushed to find other sources that are sustainable and have less emissions $[2,3]$. With the passage of time, and after long effort and research, the world found its way to produce renewable energy from different sources such as wind power, solar energy, hydropower, etc. [4-6]. Despite the tremendous boom and success in this sector, the energy produced from these technologies cannot be controlled or limited by a specific time, which requires batteries to save energy and other devices to regulate [7]. In addition to other problems related to long-distance transportation, which require a dedicated infrastructure for this and storage [8]. Therefore, the world began to think about other sources such energy conversion form various kinds of waste, including agriculture, plastic, wood, textile waste, etc. [9-13], but it is still in the development stage to eliminate the emissions and improve the conversion rate. Therefore, the world's attention has turned to hydrogen because of its high 
calorific value and zero emissions compared to other fuels $[14,15]$, due to the fact that when hydrogen is burned, only water is generated [16].

\section{Hydrogen production}

Hydrogen is produced through several methods and the most used method is by burning natural gas in the presence of water vapor and nickel metal, and here the output is either gray or blue hydrogen. Blue if the carbon dioxide produced by this process is blocked (Fig. 1) [17-19]. The other way is through renewable energy (such as electrolysis of water, solar, wind energy, etc.), which produces green hydrogen [20]. In addition to some advances techniques like fermentation [21].

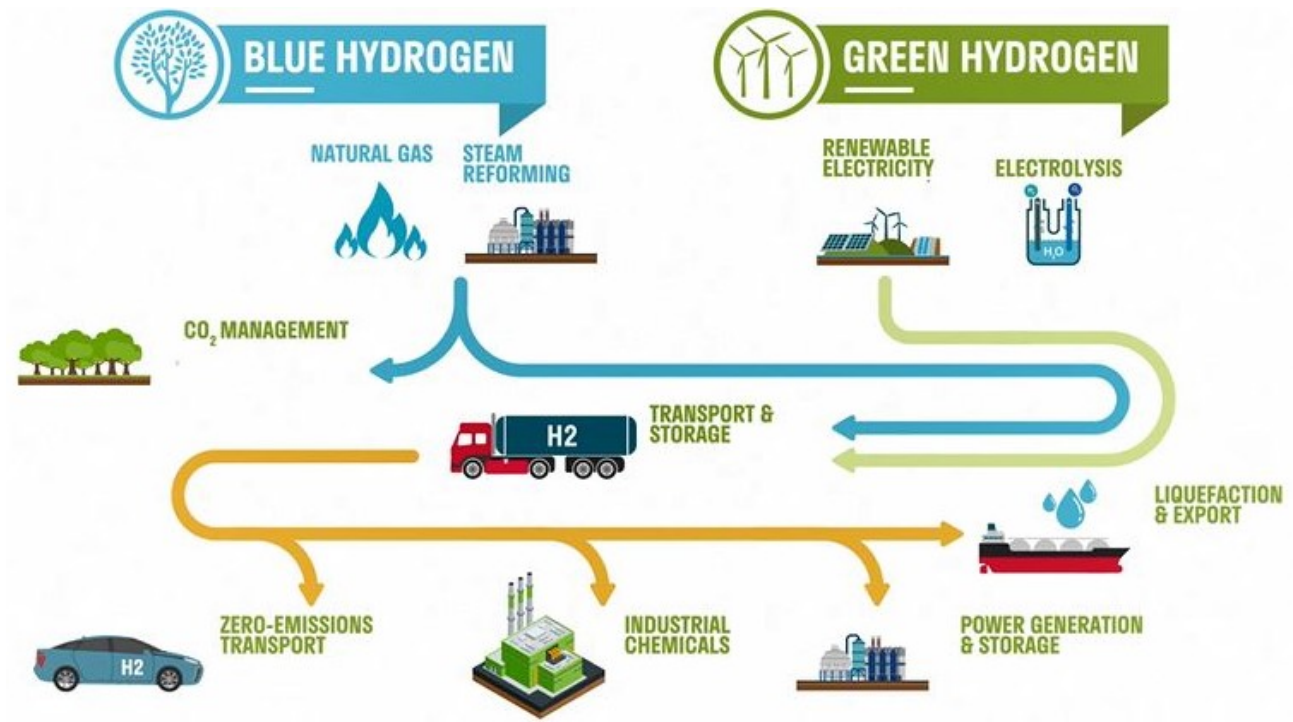

Fig. 1. Blue and green hydrogen production

\section{Hydrogen transportation and utilization}

Hydrogen is an excellent fuel for long-distance transportation from so-called fuel cells, which makes it a future choice for trucks, ships and airplanes [22]. Hydrogen is easy to transport by converting it into alumina, and its transport speed in this way is three times that of natural gas [23]. The benefits of hydrogen are not only environmental, but also economic, as hydrogen has wide uses, the most important of which is oil refining and chemical industries, such as the production of fertilizers, or in industries that require high temperatures, such as steel and glass, which are industries in which electricity cannot be used. It can also be used as fuel for power plants or even as a source of heat for heating [24-26].

\section{Global demand}

Hydrogen use is expected to reduce emissions by about $30 \%$ by 2050 [27]. Also, this is in line with the strategy of reducing carbon emissions to zero and shifting to a circular and green economy, which is supported by most countries of the world [28]. At present, the global demand for hydrogen represents $4 \%$ of the global demand for energy, with expectations of an increase in demand to $24 \%$ of global demand by 2050 [27]. Currently, there are 85 countries that require hydrogen, which suggests that there is a large market for hydrogen. And projections indicate that the hydrogen market is valued at \$ 136 billion, with expectations that it will reach $\$ 2.5$ trillion in 2050. Some estimate much higher than that $[29,30]$. 


\section{Research and development}

Recently, many of the leading countries in the energy production sector around the world have allocated large budgets in the hydrogen sector in order to study obstacles in the development and follow-up opportunities. For example, the European Union has launched a hydrogen strategy, with investments amounting to 400 billion euros, until 2030. In addition to Germany's approval of the National Hydrogen Strategy, with investments amounting to 9 billion euros [31]. The same thing in France, which has allocated 7 billion euros for the production of green hydrogen. Australia has also set up a $\$ 300$ million fund to finance hydrogen projects. In the Arab region, Saudi Arabia signed an agreement to establish the largest hydrogen plant in the world, in addition to establishing a hydrogen transmission line between it and Japan. The UAE also directed ADNOC to explore and pursue opportunities in the hydrogen sector, so it launched the first green hydrogen project in the world of its kind in the region. Recently, China planned to produce hydrogen at 12 government-owned companies.

\section{Hydrogen unit pricing}

It is expected that there will be several types of hydrogen based on the color. Hydrogen has been priced based on several calculations across the production room. The conventional cost of hydrogen has been estimated at $1.5 \mathrm{eur} / \mathrm{kg}$, while green is estimated at $3.5 \mathrm{euro} / \mathrm{kg}$. This excludes the cost of transportation and storage. Currently, there are no markets for hydrogen trading, but with the lower cost price, the prices are expected to drop. This will provide more transparency to help the market develop. And the expected feasibility to accelerate the implementation of hydrogen production. Currently, we are in a stage witnessing many projects through which it is possible to know whether it was possible to raise the efficiency of hydrogen production, as there are many projects between Saudi Arabia and Japan to find out the cost of transportation. In addition to many studies and policies to find out the actual cost. Also, global markets are currently resorting to hydrogen very quickly compared to the example of natural gas, which took nearly a decade to produce it, but hydrogen markets may witness much faster growth due to the energy and marketing of decarbonization and the role of hydrogen in the energy future.

\section{The economic viability of hydrogen production}

Hydrogen is a long-term future investment opportunity because the cost of its production is currently somewhat high. But we must remember that the same thing happened with us when the renewable energy star exploded twenty years ago, and at that time the production of solar energy or wind energy was a very costly affair. At the time, most of the hydrogen production facilities are small and there are efforts in some countries to increase their size, but the volume of investments in hydrogen must be visited to make it more sustainable and economically. We are talking here about blue and green hydrogen, which does not cause harmful emissions. At the beginning of renewable energy [32], there was support from governments. The same support had to be found with hydrogen. Also, in important issues, a carbon cost has to be found, and the hydrogen investment may be difficult to grow. There are some regions that enjoy benefiting from the hydrogen revolution, for example, if you have low-cost gas, such as the Middle East and America, then blue hydrogen can be produced at a competitive cost. But we must remember that extracting hydrogen requires bad energy from fossil fuels or renewable energy, and therefore there is a cost for this energy, and this matter makes hydrogen more expensive than other types of energy, which needs support from governments.

\section{The expectations of hydrogen production}

The Middle East is in a position to allow it from the hydrogen market due to its infrastructure 
and quantities of natural gas, and according to international energy data, the Middle East, next to China, is one of the most productive areas in China. China will likely go to green hydrogen and America to blue, as green needs growth in renewable energy production, and blue needs gas and infrastructure in the Middle East.

\section{Conclusions}

In this work, the challenges of a hydrogen fuel production and promotion were discussed. The study concluded that hydrogen production began to grow very quickly as a result of the largest investments that were pumped by the major countries. Also, burning technology is often used. This is due to the availability of infrastructure and natural gas, which is used as a basic material in its production. So gray and blue are produced. Despite the increase in green hydrogen prices, many countries have begun to encourage investors and researchers to find new solutions and methods of production. Hydrogen has also become a market in more than 85 countries around the world. So it can be considered that hydrogen is the next bright star in the clean energy train.

\section{References}

[1] Y. Wang and J. Li, "Spatial spillover effect of non-fossil fuel power generation on carbon dioxide emissions across China's provinces," Renewable Energy, Vol. 136, pp. 317-330, Jun. 2019, https://doi.org/10.1016/j.renene.2019.01.012

[2] N. Li, X. Zhang, M. Shi, and S. Zhou, "The prospects of China's long-term economic development and CO 2 emissions under fossil fuel supply constraints," Resources, Conservation and Recycling, Vol. 121, pp. 11-22, Jun. 2017, https://doi.org/10.1016/j.resconrec.2016.03.016

[3] S. Braungardt, J. van den Bergh, and T. Dunlop, "Fossil fuel divestment and climate change: Reviewing contested arguments," Energy Research \& Social Science, Vol. 50, pp. 191-200, Apr. 2019, https://doi.org/10.1016/j.erss.2018.12.004

[4] S. A. Gil Ruiz, J. E. C. Barriga, and J. A. Martínez, "Wind power assessment in the Caribbean region of Colombia, using ten-minute wind observations and ERA5 data," Renewable Energy, Vol. 172, pp. 158-176, Jul. 2021, https://doi.org/10.1016/j.renene.2021.03.033

[5] W. Wei et al., "Assessment of the solar energy accommodation capability of the district integrated energy systems considering the transmission delay of the heating network," International Journal of Electrical Power \& Energy Systems, Vol. 130, p. 106821, Sep. 2021, https://doi.org/10.1016/j.ijepes.2021.106821

[6] L. Lu et al., "Optimization model for the short-term joint operation of a grid-connected windphotovoltaic-hydro hybrid energy system with cascade hydropower plants," Energy Conversion and Management, Vol. 236, p. 114055, May 2021, https://doi.org/10.1016/j.enconman.2021.114055

[7] R. Jing, J. Wang, N. Shah, and M. Guo, "Emerging supply chain of utilising electrical vehicle retired batteries in distributed energy systems," Advances in Applied Energy, Vol. 1, p. 100002, Feb. 2021, https://doi.org/10.1016/j.adapen.2020.100002

[8] O. E. Williamson et al., "Capacidades dinâmicas como diferencial estratégico para a sustentabilidade," Journal of Business Research, 2016.

[9] C. S. Lai and G. Locatelli, "Are energy policies for supporting low-carbon power generation killing energy storage?," Journal of Cleaner Production, Vol. 280, p. 124626, Jan. 2021, https://doi.org/10.1016/j.jclepro.2020.124626

[10] H. Alhazmi and A. C. M. Loy, "A review on environmental assessment of conversion of agriculture waste to bio-energy via different thermochemical routes: Current and future trends," Bioresource Technology Reports, Vol. 14, p. 100682, Jun. 2021, https://doi.org/10.1016/j.biteb.2021.100682

[11] M. B. Al Rayaan, "Recent advancements of thermochemical conversion of plastic waste to biofuel-A review," Cleaner Engineering and Technology, Vol. 2, p. 100062, Jun. 2021, https://doi.org/10.1016/j.clet.2021.100062

[12] Z. Xu, R. Qi, M. Xiong, D. Zhang, H. Gu, and W. Chen, "Conversion of cotton textile waste to clean solid fuel via surfactant-assisted hydrothermal carbonization: Mechanisms and combustion behaviors," Bioresource Technology, Vol. 321, p. 124450, Feb. 2021, https://doi.org/10.1016/j.biortech.2020.124450 
[13] J. Li et al., "Pyrolysis characteristics and non-isothermal kinetics of waste wood biomass," Energy, Vol. 226, p. 120358, Jul. 2021, https://doi.org/10.1016/j.energy.2021.120358

[14] A. Colorado and V. McDonell, "Surface stabilized combustion technology: An experimental evaluation of the extent of its fuel-flexibility and pollutant emissions using low and high calorific value fuels," Applied Thermal Engineering, Vol. 136, pp. 206-218, May 2018, https://doi.org/10.1016/j.applthermaleng.2018.02.081

[15] M.-K. Lee, P. Sivagurunathan, Y.-M. Yun, S. Kang, J.-G. Na, and D.-H. Kim, "High-calorific biohydrogen production under self-generated high-pressure condition," Bioresource Technology, Vol. 264, pp. 174-179, Sep. 2018, https://doi.org/10.1016/j.biortech.2018.05.074

[16] X. Yu et al., "Effects of hydrogen direct injection on combustion and emission characteristics of a hydrogen/Acetone-Butanol-Ethanol dual-fuel spark ignition engine under lean-burn conditions," International Journal of Hydrogen Energy, Vol. 45, No. 58, pp. 34193-34203, Nov. 2020, https://doi.org/10.1016/j.ijhydene.2020.09.080

[17] "Solar to steer brisk EU transition from 'grey' to 'green' hydrogen economy as renewables gain preference during COVID-19 pandemic," Focus Catal., Vol. 2020, No. 11, 2020, https://doi.org/10.1016/j.focat.2020.10.010

[18] K. R. Parmar, K. K. Pant, and S. Roy, "Blue hydrogen and carbon nanotube production via direct catalytic decomposition of methane in fluidized bed reactor: Capture and extraction of carbon in the form of CNTs," Energy Conversion and Management, Vol. 232, p. 113893, Mar. 2021, https://doi.org/10.1016/j.enconman.2021.113893

[19] G. Kakoulaki, I. Kougias, N. Taylor, F. Dolci, J. Moya, and A. Jäger-Waldau, "Green hydrogen in Europe - A regional assessment: Substituting existing production with electrolysis powered by renewables," Energy Conversion and Management, Vol. 228, p. 113649, Jan. 2021, https://doi.org/10.1016/j.enconman.2020.113649

[20] "Blue Hydrogen." 2B1stconsulting. https://2b1stconsulting.com/blue-hydrogen/

[21] Y. H. Lai and J. C.-W. Lan, "Enhanced polyhydroxybutyrate production through incorporation of a hydrogen fuel cell and electro-fermentation system," International Journal of Hydrogen Energy, Vol. 46, No. 31, pp. 16787-16800, May 2021, https://doi.org/10.1016/j.ijhydene.2020.08.117

[22] H. Xing, C. Stuart, S. Spence, and H. Chen, "Alternative fuel options for low carbon maritime transportation: Pathways to 2050," Journal of Cleaner Production, Vol. 297, p. 126651, May 2021, https://doi.org/10.1016/j.jclepro.2021.126651

[23] D. Apostolou, "Optimisation of a hydrogen production - storage - re-powering system participating in electricity and transportation markets. A case study for Denmark," Applied Energy, Vol. 265, p. 114800, May 2020, https://doi.org/10.1016/j.apenergy.2020.114800

[24] J. Tang, M. Chu, F. Li, C. Feng, Z. Liu, and Y. Zhou, "Development and progress on hydrogen metallurgy," International Journal of Minerals, Metallurgy and Materials, Vol. 27, No. 6, pp. 713723, Jun. 2020, https://doi.org/10.1007/s12613-020-2021-4

[25] J. A. Okolie, B. R. Patra, A. Mukherjee, S. Nanda, A. K. Dalai, and J. A. Kozinski, "Futuristic applications of hydrogen in energy, biorefining, aerospace, pharmaceuticals and metallurgy," International Journal of Hydrogen Energy, Vol. 46, No. 13, pp. 8885-8905, Feb. 2021, https://doi.org/10.1016/j.ijhydene.2021.01.014

[26] B. Liu, S. Liu, S. Guo, and S. Zhang, "Economic study of a large-scale renewable hydrogen application utilizing surplus renewable energy and natural gas pipeline transportation in China," International Journal of Hydrogen Energy, Vol. 45, No. 3, pp. 1385-1398, Jan. 2020, https://doi.org/10.1016/j.ijhydene.2019.11.056

[27] K. G. Logan, J. D. Nelson, B. C. McLellan, and A. Hastings, "Japan and the UK: Emission predictions of electric and hydrogen trains to 2050," Transportation Research Interdisciplinary Perspectives, Vol. 10, p. 100344, Jun. 2021, https://doi.org/10.1016/j.trip.2021.100344

[28] W. He et al., "Integration of renewable hydrogen in light-duty vehicle: Nexus between energy security and low carbon emission resources," International Journal of Hydrogen Energy, Vol. 45, No. 51, pp. 27958-27968, Oct. 2020, https://doi.org/10.1016/j.ijhydene.2020.06.177

[29] D. Apostolou and S. N. Welcher, "Prospects of the hydrogen-based mobility in the private vehicle market. A social perspective in Denmark," International Journal of Hydrogen Energy, Vol. 46, No. 9 , pp. 6885-6900, Feb. 2021, https://doi.org/10.1016/j.ijhydene.2020.11.167

[30] "UNSW, PAG launch centre to push hydrogen technologies to market," Fuel Cells Bulletin, 2020. 
[31] S. Flamme et al., "ELEGANCY: The Interdisciplinary Approach of the German Case Study to Enable a Low Carbon Economy by Hydrogen and CCS," Energy Procedia, Vol. 158, pp. 3709-3714, Feb. 2019, https://doi.org/10.1016/j.egypro.2019.01.887

[32] T. L. Berg, D. Apostolou, and P. Enevoldsen, "Analysis of the wind energy market in Denmark and future interactions with an emerging hydrogen market," International Journal of Hydrogen Energy, Vol. 46, No. 1, pp. 146-156, Jan. 2021, https://doi.org/10.1016/j.ijhydene.2020.09.166

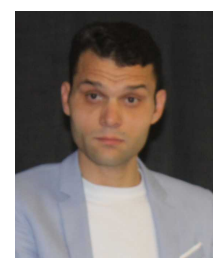

Samy Yousef has completed his Ph.D. in mechanical engineering, Cairo University, Egypt. After that, he obtained postdoctoral studies from Messina University, Italy (one year), and University of Technology, Lithuania (two years). Since 2018, He is Associate Professor, senior researcher at Faculty of Mechanical Engineering and Design, Kaunas University of Technology. He has published more than 53 papers (Scopus) in reputed journals with total impact factor $>200$ and $\mathrm{H}$ index (17). During the last four years, Dr. Yousef has achieved several promising results in materials recovery from different wastes such as WEEE, packages, solar cells, textile, and banknote waste, etc. then reprocessing of extracting metals into high added value products and adapting laboratory technology for industrial scale and Circular Economy principles. Also, he participated in developing many sustainable energy conversion strategies for textile waste, clothes dryer, plastic waste, endof-life cotton banknotes into energy products using pyrolysis technology 